\title{
Phenotype and genotype correlation of the microconversion from the CYP21A1P to the CYP21A2 gene in congenital adrenal hyperplasia
}

\author{
N. Torres ${ }^{1}$, \\ M.P. Mello ${ }^{2}$, \\ C.M.R. Germano ${ }^{3}$, \\ L.L.K. Elias ${ }^{3}$, \\ A.C. Moreira ${ }^{3}$ and \\ M. Castro $^{3}$
}

\author{
'Departamento de Patologia Clínica, Faculdade de Ciências Médicas, \\ Universidade Estadual de Campinas, Campinas, SP, Brasil \\ ${ }^{2}$ Centro de Biologia Molecular e Engenharia Genética, \\ Universidade Estadual de Campinas, Campinas, SP, Brasil \\ ${ }^{3}$ Departamento de Clínica Médica, Faculdade de Medicina de Ribeirão Preto, \\ Universidade de São Paulo, Ribeirão Preto, SP, Brasil
}

Correspondence

M. Castro

Departamento de Clínica Médica FMRP, USP

Av. Bandeirantes, 3900

14049-900 Ribeirão Preto, SP

Brasil

Fax: +55-16-633-1144

E-mail: castrom@fmrp.usp.br

Research supported by FAPESP

(No. 00/00067-8).

$\ldots \ldots \ldots \ldots \ldots \ldots$

Received July 10, 2002

Accepted May 12, 2003

\section{Abstract}

Deficiency of 21-hydroxylase is the most common form of congenital adrenal hyperplasia (CAH-21OH). We determined by allele-specific PCR the frequency of microconversion in the CYP21A2 gene in 50 Brazilian patients with the classical (salt wasting: SW and simple virilizing: SV) forms and nonclassical (NC) form of CAH-21OH and correlated genotype with phenotype. Genotypes were classified into three mutation groups (A, B, and C) based on the amount of enzymatic activity in in vitro studies using adrenal cells. In 94 unrelated alleles, we diagnosed $76 \%$ of the affected alleles after screening for 7 microconversions. The most frequent point mutations observed in this series were I172N (19\%), V281L (18\%), and IVS2,A/C > G,-12 (15\%). In the $\mathrm{SW}$ form, the most frequent mutation was IVS2,A/C $>\mathrm{G},-12$ (38\%), in the SV form it was I172N (53\%), and in the NC form it was V281L (57.7\%). We observed a good correlation between genotype and phenotype. Discordance between genotype and phenotype was found in one $\mathrm{SV}$ patient with a mild mutation in one of the alleles (R356W/V281L). However, we cannot rule out the presence of an additional mutation in these alleles. We also observed a good correlation of genotype with $17 \alpha$-hydroxyprogesterone, testosterone, and androstenedione levels. The severity of external genitalia virilization correlated with the severity of mutation. In conclusion, the frequencies described in the present study did not differ from worldwide studies, including the Brazilian population. The few differences observed may reflect individual sample variations. This new Brazilian cohort study suggests the presence of new mutations in Brazilian patients with different forms of $\mathrm{CAH}-21 \mathrm{OH}$.
Key words

- 21-Hydroxylase

- Mutation

- Microconversion

- Genotype

- Phenotype

- Congenital adrenal

hyperplasia 


\section{Introduction}

Congenital adrenal hyperplasia $(\mathrm{CAH})$ is a monogenic autosomal recessive disorder and the deficiency of 21-hydroxylase $(21 \mathrm{OH})$ accounts for $90-95 \%$ of the cases (1). Steroid $21 \mathrm{OH}$ is a cytochrome P450 enzyme that catalyzes the hydroxylation of $17 \alpha$-hydroxyprogesterone (17OHP) and progesterone during cortisol and aldosterone biosynthesis in the adrenal cortex, respectively (2). The spectrum of clinical manifestations includes a severe classical form with two phenotypic classifications, salt wasting (SW) and simple virilizing (SV), both with prenatal virilization of external genitalia in the female fetus and postnatal virilization in both sexes, and a mild nonclassical form (NC), in which patients remain asymptomatic or develop symptoms during childhood or puberty (1).

The structural gene (CYP21A2) for $21 \mathrm{OH}$ is located in the HLA class III region on the short arm of chromosome 6 (6p21.3), as also is the pseudogene $(C Y P 21 A 1 P)$. They present $98 \%$ identity in exons and are located adjacent to the genes for the complement system, $C 4 A$ and $C 4 B(3,4)$. Because of the high homology and tandem-repeat organization of the CYP21A2 and C4 genes, this region of the genome is subject to unequal crossover events and gene conversions $(5,6)$. Therefore, the mutations that account for $21 \mathrm{OH}$ deficiency can be CYP $21 A 2$ deletions, large gene conversion, or point mutations. Furthermore, other rearrangements such as duplications of either $C Y P 21 A 2+C 4 B$ or $C Y P 21 A 1 P+C 4 B$ and deletion of $C Y P 21 A 2 P$ $+C 4 B$ may also occur. Although these rearrangements are not responsible for the disease they determine different haplotypes $(7,8)$.

The frequency of CYP21A2 deletion and large gene conversion varies from 20 to $33 \%$ in several studies on Caucasian populations $(9,10)$. Deleterious mutations usually present in CYP21A1P are transferred to CYP21A2 probably by microconversion events. Micro- conversions are responsible for approximately two thirds of the affected alleles, and approximately 40 point mutations have been described (10,11). Furthermore, rare mutations have recently been described occurring only in CYP21A2 alleles (12-16). Most of them are mutations found in only one chromosome and are considered sporadic. Thirteen new different mutations have been identified in the Brazilian population (17-21). There are codons considered to be hotspots, such as W22, P30, G291, R356 and R483 (19).

In the present study we report the frequency of 7 microconversions: $\mathrm{P} 30 \mathrm{~L}, \mathrm{a} \mathrm{C}$ to $\mathrm{T}$ base change in exon 1; IVS2,A/C $>\mathrm{G},-12$, an $\mathrm{A} / \mathrm{C}$ to $\mathrm{G}$ base change in intron 2 causing abnormal RNA splicing generating a stop codon downstream; 706-713del8, an 8-bp deletion in exon 3 that generates a stop codon at position 130; I172N, a missense mutation at residue 172 in exon 4; V281L, a G to $\mathrm{C}$ base change in exon 7; Q318X, a base substitution determining a stop codon in exon 8 , and R356W, a missense mutation in exon 8 . We used an allele-specific polymerase chain reaction (PCR)-based approach in 50 Brazilian families with the classical and $\mathrm{NC}$ forms of $\mathrm{CAH}-21 \mathrm{OH}$ deficiency and correlated genotype with phenotype.

\section{Subjects and Methods}

\section{Patients}

The study was approved by the University Hospital Ethics Committee and all families gave informed consent to participate in the genetic study. We studied 5 isolated cases and 45 families including patients with $\mathrm{CAH}$ $21 \mathrm{OH}$, representing 94 unrelated affected alleles. Among the 45 families, there was only one affected subject in 42 and 2 affected subjects in 3 families. Four of these families were consanguineous. Patients were assigned to one of the three clinical forms of $\mathrm{CAH}-21 \mathrm{OH}$, defined according to standard criteria (10). Among the 50 patients, 18 pre- 
sented the SW form, 19 the SV form, and 13 the NC form. The SW form was characterized by extremely elevated concentrations of $17 \mathrm{OHP}$ and plasma renin activity, hyperkalemia, hyponatremia, and dehydration in the first months of life. All females had ambiguous genitalia, graded according to Prader staging. The SV form was characterized by ambiguous genitalia in females, sexual precocity in males without SW, and elevated plasma $17 \mathrm{OHP}$ and plasma renin activity levels. Height and bone age were advanced. The NC form was considered to be present in girls with normal external genitalia or mild clitoral enlargement and was characterized by precocious pubarche and stimulated $17 \mathrm{OHP}$ of more than $1200 \mathrm{ng} / \mathrm{dl}$ in both sexes.

\section{Hormone assays}

Serum hormones (17OHP, androstenedione and testosterone) were measured by radioimmunoassay, as previously described (17), using specific antibodies provided by Dr. José Gilberto Vieira (Fleury Laboratory). Tritiated hormones were purchased from Amersham Biosciences (São Paulo, SP, Brazil). Plasma samples were previously extracted with ether before the assays. The intra- and interassay coefficients of variation were 3.3 and $16 \%$ for 17OHP, 5.2 and $6.8 \%$ for androstenedione and 6.3 and $10 \%$ for testosterone. The sensitivity of each method was $16 \mathrm{ng} / \mathrm{dl}$ for 17OHP, $3.9 \mathrm{ng} / \mathrm{dl}$ for androstenedione, and $10 \mathrm{ng} / \mathrm{dl}$ for testosterone.

\section{Genotyping of mutations in the CYP21A2 gene}

DNA samples were obtained from peripheral blood leukocytes by standard procedures. Allele-specific PCR, as described by Wilson et al. (22), was used for the determination of 7 microconversions (P30L, IVS2,A/C $>$ G,-12, 706-713del8, I172N, V281L, Q318X, and R356W), as previously described (19). Positive and negative control DNA was used in all reactions.

\section{Genotype categories}

The patients were divided into three different genotype groups according to the impairment of plasma $210 \mathrm{OH}$ activity, as described by Speiser et al. (9). Group A included patients who were homozygous for a mutation that predicted $0 \%$ overall activity (IVS2,A/C $>$ G,-12, 706-713del8, Q318X, $\mathrm{R} 356 \mathrm{~W}$, gene deletion and macroconversion), group B included patients who were homozygous for I172N ( $2 \%$ of the enzymatic activity) or compound heterozygous with mutation from group A. Group $\mathrm{C}$ included mutations which preserve 10 to $20 \%$ of $21 \mathrm{OH}$ enzymatic activity (V281L and P30L) in homozygosity or in compound heterozygosity with mutations from group A or B.

\section{Statistical analysis}

The association of each mutation with a clinical form of the disease was determined. Differences in basal levels of 17OHP, testosterone and androstenedione among the three genotype groups were evaluated using the Wilcoxon-Mann-Whitney test.

\section{Results}

In the 94 unrelated alleles, the most frequent point mutations were I172N (19\%), V281L (18\%), and IVS2,A/C > G,-12 (15\%). In the SW form, the most frequent mutation was IVS2,A/C $>\mathrm{G},-12(38 \%)$, in the SV form it was $\operatorname{I172N}(53 \%)$, and in the $\mathrm{NC}$ form it was V281L (57.7\%). There was a significant association of IVS2,A/C $>\mathrm{G},-12, \mathrm{I} 172 \mathrm{~N}$, and V281L with the SW, SV, and NC forms, respectively $(\mathrm{P}<0.0001)$. A point mutation was present in 70 alleles, 11 of which presented 2 point mutations (Table 1). Thus, $76 \%$ of all alleles presented at least one of the 7 most frequent microconversions from CYP21A1P to CYP21A2. Among the 27 patients who had mutations identified in both 
alleles (Table 2), 8 presented the group A genotype (all of them with the SW form), 11 patients presented the group B genotype (all of them with the SV form), and 8 patients presented the group $\mathrm{C}$ genotype (7 with $\mathrm{NC}$ and 1 with SV). Virilization of the external genitalia in group A was Prader III in all female patients and varied from Prader I to III in group B (Table 1). Basal 17OHP levels ranged from 18,300 to 37,780 (median 32,620 ) in group $\mathrm{A}, 1,888$ to 36,250 (median 14,440 ) in group $\mathrm{B}$, and 308 to $8,500 \mathrm{ng} / \mathrm{dl}$ (median 1224) in group C. There was a significant difference in $17 \mathrm{OHP}$ levels among

Table 1. Genotype and clinical data of Brazilian patients with the salt wasting (SW), simple virilizing (SV) and nonclassical (NC) forms of 21-hydroxylase deficiency.

\begin{tabular}{|c|c|c|c|}
\hline Genotype & Clinical form & Age at diagnosis & $\begin{array}{l}\text { Prader stage of } \\
\text { female genitalia }\end{array}$ \\
\hline \multicolumn{4}{|l|}{ Group A } \\
\hline $\mathrm{Sp} 2 / \mathrm{Sp} 2$ & SW & 13 days & $*$ \\
\hline $\mathrm{Sp} 2 / \mathrm{Sp} 2$ & SW & at birth & III \\
\hline $\mathrm{Sp} 2 / \mathrm{Sp} 2$ & SW & 25 days & $*$ \\
\hline Q318X + R356W/Sp2 & SW & 1 month & $*$ \\
\hline $\mathrm{Sp} 2 / \mathrm{Sp} 2$ & SW & 12 days & III \\
\hline $\mathrm{Q} 318 \mathrm{X}+\mathrm{R} 356 \mathrm{~W} / \mathrm{Sp} 2$ & SW & 20 days & III \\
\hline $\mathrm{Sp} 2+\mathrm{V} 281 \mathrm{~L} / \mathrm{R} 356 \mathrm{~W}$ & SW & 34 days & III \\
\hline $\mathrm{Sp} 2 / \mathrm{Q} 318 \mathrm{X}$ & SW & 7 months & $*$ \\
\hline \multicolumn{4}{|l|}{ Group B } \\
\hline $\mathrm{I} 172 \mathrm{~N} / \mathrm{Sp} 2+\mathrm{Q} 318 \mathrm{X}$ & SV & 9 years & I \\
\hline $\mathrm{I} 172 \mathrm{~N} / \mathrm{I} 172 \mathrm{~N}$ & SV & 8 years & * \\
\hline I172N/R356W & SV & NA & II \\
\hline $\mathrm{I} 172 \mathrm{~N} / \mathrm{I} 172 \mathrm{~N}$ & SV & at birth & III \\
\hline $\mathrm{I} 172 \mathrm{~N} / \mathrm{I} 172 \mathrm{~N}$ & SV & at birth & $*$ \\
\hline $\mathrm{I} 172 \mathrm{~N} / \mathrm{I} 172 \mathrm{~N}$ & SV & at birth & * \\
\hline $\mathrm{I} 172 \mathrm{~N}+\mathrm{Q} 318 \mathrm{X} / \mathrm{I} 172 \mathrm{~N}$ & SV & 2 years and 7 months & $*$ \\
\hline I $172 \mathrm{~N} / \mathrm{I} 172 \mathrm{~N}$ & SV & 4 years & $*$ \\
\hline $\mathrm{Q} 318 \mathrm{X}+\mathrm{R} 356 \mathrm{~W} / \mathrm{I} 172 \mathrm{~N}$ & SV & at birth & III \\
\hline $\mathrm{I} 172 \mathrm{~N} / \mathrm{Sp} 2+\mathrm{Q} 318 \mathrm{X}$ & SV & 1 year and 1 month & I \\
\hline $\mathrm{I} 172 \mathrm{~N} / \mathrm{I} 172 \mathrm{~N}$ & SV & 5 years and 7 months & * \\
\hline \multicolumn{4}{|l|}{ Group C } \\
\hline V281L/V281L & $\mathrm{NC}$ & at birth & $\mathrm{N}$ \\
\hline R356W/V281L & $\mathrm{NC}$ & 5 years & I \\
\hline V281L/V281L & $\mathrm{NC}$ & 6 years & $\mathrm{N}$ \\
\hline V281L/V281L & $\mathrm{NC}$ & 4 years and 9 months & $\mathrm{N}$ \\
\hline $\mathrm{R} 356 \mathrm{~W} / \mathrm{V} 281 \mathrm{~L}$ & $\mathrm{NC}$ & 6 years & $\mathrm{N}$ \\
\hline V281L/V281L & $\mathrm{NC}$ & 6 years & $\mathrm{N}$ \\
\hline V281L/V281L & $\mathrm{NC}$ & 12 years & $*$ \\
\hline $\mathrm{R} 356 \mathrm{~W} / \mathrm{V} 281 \mathrm{~L}$ & SV & 4 years & I \\
\hline
\end{tabular}

*: male patients; $\mathrm{N}$ : normal genitalia; NA: not available; Sp2: the intronic mutation IVS2,A/C $>\mathrm{G},-12$. the three groups. Androstenedione levels ranged from 144 to 7,225 (median 989) in group A, 58 to 3,102 (median 408) in group $\mathrm{B}$, and 24 to $351 \mathrm{ng} / \mathrm{dl}$ (median 118) in group C. Testosterone levels ranged from 32 to 648 (median 263) in group A, 59 to 466 (median 98) in group B, and 12 to $121 \mathrm{ng} / \mathrm{dl}$ (median 32 ) in group C. Androstenedione and testosterone levels were similar in groups $\mathrm{A}$ and $\mathrm{B}$, and these groups presented higher levels compared to group $\mathrm{C}$.

\section{Discussion}

We report here the frequencies of some CYP21A2 gene mutations (P30L, IVS2, $\mathrm{A} / \mathrm{C}>\mathrm{G},-12,706-713 \mathrm{del} 8, \mathrm{I} 172 \mathrm{~N}, \mathrm{~V} 281 \mathrm{~L}$, $\mathrm{Q} 318 \mathrm{X}$, and $\mathrm{R} 356 \mathrm{~W})$, which may be introduced into CYP21A2 from CYP21A1P by microconversion events, in a new Brazilian cohort with classical and $\mathrm{NC}$ forms of CAH$21 \mathrm{OH}$ deficiency. We characterized affected alleles by analysis of the families and correlated genotype with phenotype. As duplication, deletion and gene macroconversion events generated from hybrid genes cannot be amplified using only PCR-based methods, future Southern blot analyses are required to identify these rearrangements in every individual involved in this study.

The ethnic origin of the Brazilian population is extremely heterogeneous. There are not many data available on the genetic characteristics of the CYP21A2 gene in this country (17-21). In the present study we detected at least one mutation in $76 \%$ of the diseasecausing alleles. The two previous Brazilian populations screened for the most frequent mutations, which included gene deletion, large gene conversion, and microconversions, presented an affected allele at a frequency of $80 \%$ (18) and $85 \%$ (19). Therefore, the results of the present study confirm that in the Brazilian population about $15-25 \%$ of the remaining disease alleles were not elucidated and might carry other rare or novel mutations. Reports on the general popula- 
Table 2. Frequency of mutation in Brazilian patients with the classical (salt wasting: SW and simple virilizing: $\mathrm{SV}$ ) and nonclassical (NC) forms of 21-hydroxylase deficiency.

\begin{tabular}{|c|c|c|c|c|c|c|}
\hline & \multicolumn{4}{|c|}{ Present study } & \multirow[t]{2}{*}{ Paulino et al. (19) } & \multirow[t]{2}{*}{ Bachega et al. (18) } \\
\hline & SW & SV & $\mathrm{NC}$ & Total & & \\
\hline Alleles (n) & 33 & 32 & 26 & 91 & 68 & 228 \\
\hline P30L & - & - & $\begin{array}{c}1 \\
3.8 \%\end{array}$ & $\begin{array}{c}1 \\
1.1 \%\end{array}$ & ND & $\begin{array}{c}5 \\
2.2 \%\end{array}$ \\
\hline $\mathrm{Sp} 2$ & $\begin{array}{c}12 \\
48 \%\end{array}$ & $\begin{array}{c}2 \\
6 \%\end{array}$ & - & $\begin{array}{c}14 \\
14 \%\end{array}$ & $26 \%$ & $\begin{array}{c}47 \\
20 \%\end{array}$ \\
\hline$\Delta 8$ & $\begin{array}{c}1 \\
3 \%\end{array}$ & - & - & $\begin{array}{c}1 \\
1.1 \%\end{array}$ & $1.4 \%$ & $\begin{array}{l}3 \\
1.3 \%\end{array}$ \\
\hline $\mathrm{I} 172 \mathrm{~N}$ & - & $\begin{array}{c}18 \\
56 \%\end{array}$ & - & $\begin{array}{c}18 \\
20.4 \%\end{array}$ & $20.5 \%$ & $\begin{array}{c}32 \\
14 \%\end{array}$ \\
\hline V218L & $\begin{array}{c}1 \\
3 \%\end{array}$ & $\begin{array}{c}1 \\
3 \%\end{array}$ & $\begin{array}{c}15 \\
57.7 \%\end{array}$ & $\begin{array}{c}17 \\
18.2 \%\end{array}$ & $4.5 \%$ & $\begin{array}{c}41 \\
18 \%\end{array}$ \\
\hline Q318X & $\begin{array}{c}1 \\
3 \%\end{array}$ & - & - & $\begin{array}{c}1 \\
1.1 \%\end{array}$ & $12 \%$ & $\begin{array}{c}5 \\
5.7 \%\end{array}$ \\
\hline R356W & $\begin{array}{c}1 \\
3 \%\end{array}$ & $\begin{array}{c}3 \\
9 \%\end{array}$ & $\begin{array}{c}2 \\
7.7 \%\end{array}$ & $\begin{array}{c}6 \\
6.5 \%\end{array}$ & $9 \%$ & $\begin{array}{c}16 \\
7 \%\end{array}$ \\
\hline $\mathrm{P} 30 \mathrm{~L}+\mathrm{I} 172 \mathrm{~N}$ & - & - & $\begin{array}{c}1 \\
3.8 \%\end{array}$ & $\begin{array}{c}1 \\
1.1 \%\end{array}$ & ND & ND \\
\hline $\mathrm{I} 172 \mathrm{~N}+\mathrm{Q} 318 \mathrm{X}$ & - & $\begin{array}{c}1 \\
3 \%\end{array}$ & - & $\begin{array}{c}1 \\
1.1 \%\end{array}$ & ND & ND \\
\hline $\mathrm{I} 172 \mathrm{~N}+\mathrm{V} 281 \mathrm{~L}$ & - & - & $\begin{array}{c}1 \\
3.8 \%\end{array}$ & $\begin{array}{c}1 \\
1.1 \%\end{array}$ & ND & ND \\
\hline Q318X + R356X & $\begin{array}{c}2 \\
6 \%\end{array}$ & $\begin{array}{c}1 \\
3 \%\end{array}$ & - & $\begin{array}{c}3 \\
3.7 \%\end{array}$ & ND & ND \\
\hline $\mathrm{Sp} 2+\mathrm{Q} 318 \mathrm{X}$ & - & $\begin{array}{c}2 \\
6 \%\end{array}$ & - & $\begin{array}{c}2 \\
2.2 \%\end{array}$ & ND & ND \\
\hline $\mathrm{Sp} 2+\mathrm{R} 356 \mathrm{~W}$ & $\begin{array}{c}1 \\
3 \%\end{array}$ & - & - & $\begin{array}{c}1 \\
1.1 \%\end{array}$ & ND & ND \\
\hline $\mathrm{Sp} 2+\mathrm{V} 281 \mathrm{~L}$ & $\begin{array}{c}1 \\
3 \%\end{array}$ & - & - & $\begin{array}{c}1 \\
1.1 \%\end{array}$ & ND & ND \\
\hline $\mathrm{Sp} 2+\Delta 8$ & $\begin{array}{c}1 \\
3 \%\end{array}$ & - & - & $\begin{array}{c}1 \\
1.1 \%\end{array}$ & ND & ND \\
\hline Conv & - & - & - & ND & $13.5 \%$ & $7 \%$ \\
\hline Del & - & - & - & ND & $8.1 \%$ & $5 \%$ \\
\hline
\end{tabular}

Conv: conversion; Del: deletion; $\Delta 8$ : 706-713del8; ND: not determined; Sp2: the intronic mutation IVS2, $\mathrm{A} / \mathrm{C}>\mathrm{G},-12$. 
tion diagnosed 77.6 to $95 \%$ of the alleles $(10,18,19,23-25)$. The highest frequency of undiagnosed alleles was also found in other Latin-American studies $(24,26)$. More recently, Billerbeck et al. (20), Bachega et al. (21), and Lau et al. (27) have demonstrated the presence of novel mutations in the CYP21A2 gene in the Brazilian population. Further studies searching for these mutations described in previous Brazilian populations are required not only for the present series, but also for other populations in order to reveal if they are restricted to the Brazilian ethnic background. In addition to the alleles carrying one mutation, alleles with more than one mutation are not rare and have been observed by segregation analysis in family studies $(13,18,28)$. In the present study we found that $15.8 \%$ of patients had alleles carrying more than one mutation; most of them were compound heterozygotes, and the clinical form was correlated with the mutated allele with higher enzymatic activity $(10,26,29)$.

In the 94 unrelated alleles studied in the present series the most frequent mutations were I172N, V281L, and IVS2,A/C $>\mathrm{G},-12$. In the $\mathrm{SW}$ form, the most frequent mutation was IVS2,A/C $>\mathrm{G},-12$, in the SV form it was I172N, and in the NC form it was V281L, showing a significant association between these mutations and the clinical forms of the disease. These results are similar to those obtained in previous reports, in which the intron 2 mutation was the most common, with frequencies ranging from 18 to $36 \%$, followed by I172N mutation (10). Our study showed the highest frequency for I $172 \mathrm{~N}$ when compared to others. This result might reflect differences in the proportion of SV cases in each sample. V281L is generally associated with the NC form of the disease $(29,30)$ and was found at a high frequency $(57.7 \%)$ in our sample, which also included NC patients. An association of V281L in the same allele with another mutation (R356W and P30L) was also observed and was associated with the classical form of the disease. In addition, it is important to point out that V281L can occur associated with duplication of CYP21A1P, as previously reported (30), and alleles carrying duplication of CYP21A1P seem to be in linkage disequilibrium with the $\mathrm{NC}$ form of CAH. In the 27 patients genotyped for both alleles, we found a high frequency $(59 \%)$ of homozygosity for point mutations that has not been commonly reported in the literature. It is important to point out that some of these cases might be hemizygous and, more unlikely, they might present a de novo mutation. To clarify this point it is necessary to perform Southern blots and to sequence the entire CYP21A2 gene.

We observed a good, although not absolute, correlation between genotype and phenotype $(10,11)$. Twenty-seven patients had mutations identified in both alleles. From these patients, 8 presented the group A genotype (all of them with the SW form), 11 presented the group B genotype (all of them with the SV form), and 8 presented the group C genotype (7 with NC and 1 with SV). Therefore, a discrepancy between genotype and phenotype was found in only one patient having the SV form. We cannot rule out the possibility of presence of an additional new mutation in these alleles or abnormalities in the regulatory region of the gene. Because of the discrepancy between phenotype and genotype in some cases, a phenotype prediction should be made with caution in prenatal diagnosis based on molecular genetic analysis of fetal DNA. We also observed a good correlation of genotype with 17OHP, testosterone, and androstenedione levels, which reflects the extent of enzymatic activity impairment. The degree of hyperandrogenism also correlated with the severity of neonatal external genitalia virilization, mainly in group A.

Despite the mixture of diverse ethnic origins in the Brazilian population, the mutation frequencies described in the present study did not differ from previous world- 
wide and Brazilian studies. The few differences observed may reflect subtle sample variation in the ethnic background of the studied population. This new Brazilian cohort study may suggest the presence of other mutations in Brazilian patients with different forms of CAH-21OH. The establishment of genotypes in complete families with at least one individual affected with $\mathrm{CAH}-21 \mathrm{OH}$ is useful for genetic counseling, prenatal diagnosis and prenatal treatment strategies.

\section{Acknowledgments}

We thank Drs. P.C. White from the University of Texas, Southwestern Medical Center, Dallas, TX, USA and T. Strachan from the University Department of Medical Genetics, Saint Mary's Hospital, Manchester, United Kingdom for providing the $\mathrm{pC} 21 / 3 \mathrm{c}$ and $\mathrm{C} 4 \mathrm{~B} 550$ probes, respectively. We are grateful to Maria Madalena V. Rosa for technical assistance.

\section{References}

1. Orth DN \& Kovacs WJ (1998). The adrenal cortex. In: Wilson JD, Foster DW, Kronenberg HM \& Larsen RP (Editors), Williams Textbook of Endocrinology. Saunders, Philadelphia, PA, USA.

2. Strachan T (1994). Molecular pathology of 21-hydroxylase deficiency. Journal of Inherited Metabolic Disease, 17: 430-441.

3. White PC, Grossberger D, Onufer BJ, Chaplin DD, New MI \& Dupont B (1985). Two genes encoding steroid 21-hydroxylase are located near the genes encoding the fourth component of complement in man. Proceedings of the National Academy of Sciences, USA, 82: 1089-1093.

4. Carroll MC, Campbell RD \& Porter RR (1985). Mapping the steroid 21-hydroxylase adjacent complement component C4 genes in HLA major histocompatibility complex in man. Proceedings of the $\mathrm{Na}$ tional Academy of Sciences, USA, 82: 521-525.

5. Higashi $Y$, Tanae A, Inoue H \& Fuji-Kuriyama Y (1988). Evidence for frequent gene conversions in the steroid 21-hydroxylase (P-450c21) gene: implications for steroid 21-hydroxylase deficiency. American Journal of Human Genetics, 42: 17-25.

6. New MI, Lorenzen F, Lerner AJ et al. (1983). Genotyping steroid 21hydroxylase deficiency: hormonal reference data. Journal of Clinical Endocrinology and Metabolism, 57: 320-326.

7. White PC, Vitek A, Dupont B \& New MI (1988). Characterization of frequent deletions causing steroid 21-hydroxylase deficiency. Proceedings of the National Academy of Sciences, USA, 85: 44364440.

8. Koppens PF, Hoogenboezem T, Halley DJ, Barendse CA, Oostenbrink AJ \& Degenhart HJ (1992). Family studies of the steroid 21hydroxylase and complement C4 genes define 11 haplotypes in classical congenital adrenal hyperplasia in The Netherlands. European Journal of Pediatrics, 151: 885-892.

9. Speiser PW, Dupont J, Zhu D, Serrat J, Buegeleisen M, Tusie-Luna MT, Lesser M, New MI \& White PC (1992). Disease expression and molecular genotype in congenital adrenal hyperplasia due to 21hydroxylase deficiency. Journal of Clinical Investigation, 90: 584595.

10. White PC \& Speiser PW (2000). Congenital adrenal hyperplasia due to 21-hydroxylase deficiency. Endocrine Reviews, 21: 245-291.

11. Wedell A \& Luthman H (1993). Steroid 21-hydroxylase (P450c21): a new allele and spread of mutations through the pseudogene. Human Genetics, 91: 236-240.

12. Levo A \& Partanen J (1997). Mutation-haplotype analysis of steroid 21-hydroxylase (CYP21) deficiency in Finland. Implications for the population history of defective alleles. Human Genetics, 99: 488497.

13. Wedell A, Ritzen EM, Haglund-Stengler B \& Luthman H (1992). Steroid 21-hydroxylase deficiency: three additional mutated alleles and establishment of phenotype-genotype relationships of common mutations. Proceedings of the National Academy of Sciences, USA, 89: 7232-7236.

14. Helmberg A, Tusie-Luna MT, Tabarelli M, Kofler R \& White PC (1992). R339H and P453S: CYP21 mutations associated with nonclassic steroid 21-hydroxylase deficiency that are not apparent gene conversions. Molecular Endocrinology, 6: 1318-1322.

15. Lajic S \& Wedell A (1996). An intron 1 splice mutation and nonsense mutation (W23X) in CYP21 causing severe congenital adrenal hyperplasia. Human Genetics, 98: 182-184.

16. Nikoshkov A, Lajic S, Vlamis-Gardikas A, Tranebjaerg L, Holst M \& Wedell A (1998). Naturally occurring mutants of human steroid 21hydroxylase (P450c21) pinpoint residues important for enzyme activity and stability. Journal of Biological Chemistry, 273: 6163-6165.

17. Oliveira MHA, Moreira AC, Rossi A \& Cruz C (1991). Salivary 17alpha-hydroxyprogesterone in management of congenital adrenal hyperplasia. Journal of Pediatric Endocrinology, 4: 255-262.

18. Bachega TA, Billerbeck AEC, Madureira G, Marcondes JAM, Longui CA, Leite MV, Arnhold IJ \& Mendonça BB (1998). Molecular genotyping in Brazilian patients with classical and nonclassical forms of 21-hydroxylase deficiency. Journal of Clinical Endocrinology and Metabolism, 83: 4416-4419.

19. Paulino L, De Araujo M, Guerra Jr G, Marini SHLV \& De Mello MP (1999). Mutation distribution and CYP21/C4 locus variability in Brazilian families with the classical form of the 21-hydroxylase deficiency. Acta Paediatrica, 88: 275-283.

20. Billerbeck AE, Bachega TA, Frazatto ET, Nishi MY, Goldberg AC, Marin ML, Madureira G, Monte O, Arnhold IJ \& Mendonça BB (1999). A novel missense mutation, GLY424SER, in Brazilian patients with 21-hydroxylase deficiency. Journal of Clinical Endocrinology and Metabolism, 84: 2870-2872.

21. Bachega TA, Brenlha EM, Billerbeck AE, Marcondes JA, Madureira G, Arnhold IJ \& Mendonça BB (2002). Variable ACTH-stimulated 17hydroxyprogesterone values in 21-hydroxylase deficiency carriers are not related to the different CYP21 gene mutations. Journal of Clinical Endocrinology and Metabolism, 87: 786-790. 
22. Wilson RC, Wei JQ, Cheng KC, Mercado AB \& New MI (1995). Rapid deoxyribonucleic acid analysis by allele-specific polymerase chain reaction for detection of mutations in the 21-hydroxylase gene. Journal of Clinical Endocrinology and Metabolism, 80: 16351640.

23. Mornet E, Crété P, Kuttenn F, Raux-Demay M-C, Boué J \& White PC (1991). Distribution of deletions and seven point mutations on CYP21B genes in three clinical forms of steroid 21-hydroxylase deficiency. Human Genetics, 48: 79-88.

24. Ordonez-Sánchez ML, Ramírez-Jiménez S, López-Gutierrez AU et al. (1998). Molecular genetic analysis of patients carrying steroid 21 hydroxylase deficiency in the Mexican population: identification of possible new mutations and high prevalence of apparent germline mutations. Human Genetics, 102: 170-177

25. Jääkeläinen J, Levo A, Voutilainen R \& Partanen J (1997). Population-wide evaluation of disease manifestation in relation to molecular genotype in steroid 21-hydroxylase (CYP21) deficiency: good correlation in a well defined population. Journal of Clinical Endocrinology and Metabolism, 82: 3293-3297.

26. Dardis A, Bergada I, Bergada C, Rivarola M \& Belgorosky A (1997).
Mutations of the steroid 21-hydroxylase gene in an Argentinian population of 36 patients with classical congenital adrenal hyperplasia. Journal of Pediatric Endocrinology and Metabolism, 10: 55-61.

27. Lau IF, Soardi FC, Lemos-Marini SH, Guerra Jr G, Baptista MT \& De Mello MP (2001). H28+C insertion in the CYP21 gene: a novel frameshift mutation in a Brazilian patient with the classical form of 21-hydroxylase deficiency. Journal of Clinical Endocrinology and Metabolism, 86: 5877-5880.

28. Wedell A, Chun S \& Luthman H (1994). A steroid 21-hydroxylase allele concomitantly carrying four disease-causing mutations is not uncommon in the Swedish population. Human Genetics, 93: 204206.

29. Carrera P, Bordone L, Azzani T, Brunelli V, Garancini MP \& Chiumello $G$ (1996). Point mutations in Italian patients with classic, non-classic, and cryptic forms of steroid 21-hydroxylase deficiency. Human Genetics, 98: 662-665.

30. Speiser PW, New MI \& White PC (1988). Molecular genetic analysis of nonclassic steroid 21-hydroxylase deficiency associated with HLA-B14, DR1. New England Journal of Medicine, 319: 19-23. 